\title{
Tsunami Disaster Preparedness Simulation on North Buton Regency
}

\author{
Jajang Sanjaya \\ Agency of Public Works and Spatial Arrangement, North Buton Regency, INDONESIA \\ jjsanjaya@gmail.com
}

\begin{abstract}
Geographical location of North Buton Regency which directly opposite the Banda Sea and placed in the reverse fault of Makassar Strait, Matano fault, Lawanoppo, and Kolaka, which are tsunami-prone areas due to earthquake and submarine landslide. These then caused the area has high disaster risk, because of the settlement that is located on the seashore. Therefore, a study to understand the preparedness level of community in North Buton Regency in confronting the tsunami disaster is needed; in order to be able to determine the mitigation steps, also the effective evacuation route and location to minimize the casualties caused by tsunami. Kulisusu Sub-district is a territory with a fairly long coastal area, wherein the population density is the highest in North Buton Regency, this then made the area has high disaster risk. This research used questionnaire instrument to discover the preparedness level of the community, and the numerical simulation method with multi-agent system in the tsunami evacuation simulation. The conducted simulation did not specify the evacuation route or path, yet the agents were allowed to move freely to the shelter. The simulation was conducted at day and night time. The result of the research pointed on matter of preparedness level of community, in which factor of preparedness of the community in facing the disaster is very important, by the means of establishing simulation drill, preparing the controller officers, and managing the comfort on the shelter, such as strategic location and good position, also creating a good early warning system so that more residents could be saved.
\end{abstract}

Keywords: preparedness of simulation; tsunami; evacuation; multi-agent

\section{INTRODUCTION}

Interaction and convergence of the three plates-the Indo-Australian, Eurasia, and Pacific-which are centered on the eastern part of Indonesia, resulted in active tectonic zones, these includes the subduction zone, collision zone, and fault zone such as Banda Sea collision zone, which has potency to generate earthquake and tsunami disasters if the plates collide. The characteristic of tsunamigenic earthquake in Indonesia showed that $67 \%$ of tsunami in Indonesia happened in the eastern part of the country; for the time period between 1600 and 2004, there had been approximately 109 tsunamis in eastern Indonesia.

North Buton Regency that located directly opposite the Banda Sea is very vulnerable to tsunami disaster that is caused by submarine volcanic eruption, submarine landslide, or earthquake occurred in ocean. Based on the Tsunami Disaster Risk Index Map of Southeast Sulawesi Province, North Buton Regency has a high risk level for tsunami disaster threat.

On the coastal area of North Buton Regency, the region has a high population density. As the number of people that live in the coastal area is increasingly getting higher, the lack of mitigation effort that the government has done and the low understanding and preparedness of the community in facing the threat of tsunami hazard, the risk of tsunami disaster could get higher.
Therefore, it is necessary to have a good mitigation plan for the community evacuation, to avoid and to reduce casualties in the disaster-prone coastal area, and to lower the disaster risk.

\section{TSUNAMI, PREPAREDNESS, AND EVACUATION}

Tsunami is a wave occurred due to earthquake or volcanic eruption in the ocean. The wave that occurred is varied from $0.5 \mathrm{~m}$ up to $30 \mathrm{~m}$, and from the period of several minutes up to around one hour. In contrast with the waves (wind) that only move seawater at surface level, in tsunami, the entire water column from surface to the bottom moves in all directions. The propagation velocity of the tsunami wave depends on the sea depth. The greater the depth, the greater the velocity of propagation will be (Triadmodjo, 1999).

Preparedness is one of important elements in disaster mitigation that is pro-active-before the disaster occurred. Community preparedness is more focused on preparing the ability to be able to conduct emergency response activities quickly and appropriately.

In simple, evacuation could be defined as people or community movement, from an area or from a situation threatened by a disaster event, to a safer area (Munadi, et al., 2012). 
There are two types of evacuation, which are:

a) Horizontal evacuation, which is evacuation by horizontally moving residents to a safer place, so as to avoid tsunami incursion; it is usually done by moving away from the seashore;

b) Vertical evacuation, in which the residents stay on the coast, but reach up to higher construction that could be functioned as a shelter.

\section{TSUNAMI PREPAREDNESS SIMULATION}

To supply the community with knowledge on disaster preparedness, intensive socialization and preparedness drill is necessary. The problems are limited budget and the difficultness to persuade a large-scale mass to participate. One of the ways to deal with this problem is by building and developing evacuation simulation. Even though the result of the simulation is not entirely matching with reality, at least it could minimalize negative consequence because of the drill implementation, and also could give input and insight in strengthening the rescue strategy (Munadi, et al., 2012)

\subsection{Analysis of community preparedness level}

Discovering the level of community preparedness in this research was by referring to component of preparedness stated by LIPI UNESCO/ISDR (2006), which is consisted of several parameters: first is the knowledge on tsunami disaster, second is the tsunami disaster response plan, third is the tsunami disaster mitigation, and fourth is the resources evacuation mobilization, also the fifth that is the element of intention in the studied parameters, which is intended to gain information and intention to conduct preparation (Nurhayaty, 2015). Preparedness level can be classified into several categories as can be seen in Table 1.

Table 1. Category on preparedness level

\begin{tabular}{lll}
\hline No & Total Index & Category \\
\hline 1. & $80-100$ & Very Ready \\
2. & $65-79$ & Ready \\
3. & $55-64$ & Almost Ready \\
4. & $40-54$ & Less Ready \\
5. & Less than $40(0-39)$ & Not Ready \\
\hline
\end{tabular}

\subsection{Preparedness Simulation with Evacuware Software Version 2011}

Previous research that has conducted Evacuware Software Version 2011 simulation program was by Rhamo (2014) in Parangtritis Beach, Yogyakarta; in Bengkulu City by Nasution (2014); and in Bumi Waras Sub-district in Bengkulu by Dhodi (2014). The three of them used the Evacuware Software Version 1.0 in 2011; however it has similarity in terms of the utilization of orientation menu to determine the evacuation route, therefore the evacuation simulation ran based on the pre-determined route.

\subsection{Plan for Tsunami Preparedness Simulation in Kulisusu Sub-district}

North Buton Regency has a diverse topography, from coastal plains to hills. In this topography condition, the Kulisusu Sub-district has a relatively low elevation compared with all coastal areas in North Buton Regency, which is around 0-5 m above sea level. Location of Kalisusu Subdistrict can be seen in Figure 1.

There were several assumptions used to conduct the simulation in this research, including as follows:

a) The time people conduct evacuation is daytime and night time;

b) Evacuation is only conducted on foot, therefore simulation by motor vehicle is not conducted;

c) Motor vehicle is considered to be a hindrance for the community when doing the evacuation;

The tsunami evacuation scenario in Kulisusu Subdistrict would be conducted in several simulation scenarios, including as follows:

a) The evacuation location in Keraton Lipu,

b) The evacuation location in Office Complex of Bumi Sara Ea,

c) The evacuation location in Office Complex of Bumi Sara Ea dan Fort Keraton Lipu,

d) Tsunami travel time is 60 minutes from its source;

e) Infants, toddlers, and seniors/elderly people are paired with young residents;

f) Residents are conditioned to be on road on each of its village's area;

g) Survived resident is the one who arrives at evacuation location until the tsunami arrival time.

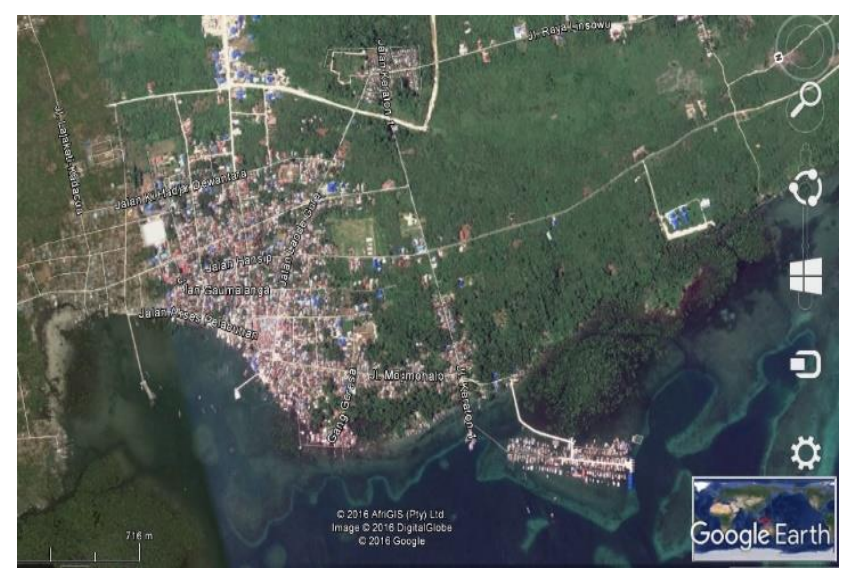

Figure 1. Satellite Map on Coastal Area of Kulisusu Subdistrict, North Buton Regency (Source: Google Earth) 


\section{RESEARCH METHOD}

This research was to be conducted in the area of Kulisusu Sub-district, which is a highly dense populated area, one of the economic centers in North Buton Regency, in which there are markets, stores, ports, fishing ports, settlements, and one of the centers of business and entertainment. Based on the Statistics Indonesia (Badan Pusat Statistik Kabupaten Buton Utara, 2015) data on North Buton Regency at 2015, the population of Kulisusu Sub-district is of 22,688 people with density level of 13,903 people $/ \mathrm{km}^{2}$.

\subsection{Initial Identification Stage}

Including the location determination, problem formulation, objectives, and review of literature that are related to the research

\subsection{Data Collecting Stage}

The data that was obtained is location of the planned evacuation in the Keraton Lipu and Office Complex of Bumi Sara Ea, map of research location was acquired from Google Maps and from Regional Planning Board (Bappeda) of North Buton Regency, the condition of road infrastructure and the plan for final evacuation site was based on observation result on field and population data was acquired from Statistics Indonesia (Badan Pusat Statistik) of North Buton Regency.

\subsection{Preparedness Level Research Stage}

Measuring instrument used was questionnaires that were distributed to samples in community, by using the method of simple random sampling, whereas the questionnaire is delivered to random population member, in which all have the equal chance to be chosen, and once not chosen, then it could not be chosen again. The subjects that were taken in this research were community members that conduct activities at around the coastal area, and community that lives in the area of Lipu Village, Lakonea Village, Banu-banua Jaya Village, and Wandaka Village, both with or without identity card.

Based on the number of variables or parameters of the used samples, the minimum size of the samples is 200 samples.

The behavior of tsunami preparedness was measured with the tsunami preparedness scale that was used by LIPI UNESCO/ISDR (2006), plus the element of intention on conducting the preparedness (Nurhayaty, 2015). The higher the preparedness score that is acquired, the higher the understanding that individual person has on performing the preparation steps before the tsunami occurred.
Interviews were performed to community leaders, government officials, and non-governmental organization.

\subsection{Data Processing Stage}

a) Test on Validity and Reliability of Measuring Instrument

For a question to be considered as valid if every question items that arranged the questionnaire have high correlation. The size of this correlation between questions is usually reflected by the correlation of the answers between questions. It was conducted with software SPSS 20, which was by comparing r-calculate results on the corrected item total correlation column with the $r$ value on the table of Pearson productmoment Correlation coefficient, on significance level of $5 \%$. If the obtained value of correlation coefficient $(r) \geq r$-table, then the tested instrument is considered to be valid. Reliability of a variable is considered to be good if the Cronbach's alpha value is higher than 0.5.

\section{b) Index Analysis}

After the scoring value from the questionnaire was obtained, the index analysis was conducted, this was used to discover the preparedness level of the community to tsunami disaster. An index is a comparative number of each number that contains information about a particular characteristic at the same or different time and place. To make it simpler and more understandable, the comparative value is multiplied by 100 . The index for each parameter was calculated based on the formulation:

Index $=\frac{\text { Total score } \mathrm{r} \text { of real parameter }}{\text { parameter maximum score }} \times 100$

\section{c) Correlation Analysis}

Correlation analysis was used to discover whether there is a link between two or more variables. To find out the relationship between education levels with community response with preparedness level to tsunami disaster, Pearson product-moment Correlation statistic test was used, with hypothesis as follows:

$H_{0}=$ no correlation between respondent's education level with preparedness index.

$H_{l} \quad=$ there is correlation between respondent's education level with preparedness index.

The significance level used is of $5 \%$. 
Correlation between respondent's education levels with level of preparedness to tsunami disaster was calculated by comparing $t_{\text {calculate }}$ value with value from $t_{\text {table. }}$. If the $t_{\text {calculate }}$ value is larger from the $t_{\text {atble }}$, the $\mathrm{H}_{1}$ hypothesis that stated correlation between education levels with preparedness index could be accepted. The correlation $(r)$ according to Azwar (1998), is $\mathrm{r}$ value = $0.00-0.20$, very weak correlation; $r=0.21-0.41$, correlation weak; $r=0.41-0.60$, correlation quite strong; $r=0.81-1.00$, correlation is very strong.

\section{d) Confirmatory Factor Analysis}

Confirmatory analysis was conducted to discover the inter-relation pattern so the matrix used was correlation matrix. The data analysis technique used the Structural Equation Modeling (SEM) for explaining thoroughly the relation among variables. The program used was AMOS 20 which would convert questionnaire data to covariance form or correlation as the analysis input from Ghozali (2008). The AMOS standard estimation model used the maximum likelihood (ML) estimator.

\section{e) Tsunami Evacuation Simulation}

The data was processed using Evacuware Software 2.0 Version in 2011. The discussion in this research was limited to time required for evacuation, final evacuation site, and also considered the condition in which vehicles were not used, conducted after earthquake occurred or when the early warning for tsunami lighted up, the survived residents were the ones who arrive at evacuation location in less than 60 minutes, and all residents are on the street. There were several scenarios in this research as listed in Table 1, in order to get good vertical evacuation location, in the form of high land or building, such as all residents were conditioned to be on the road, and the determined final evacuation site was Complex of Fort Keraton Lipu, the determined final evacuation site was the Office Complex of Bumi Sara Ea, as aforementioned points but the determined final evacuation sites were Fort Keraton Lipu and Office Complex Bumi Sara Ea, without any arrangement, and with a setting on friction value of road to the final evacuation site of Fort Lipu.

Table 2. Simulation scenario

\begin{tabular}{ll}
\hline Simulation & Shelter \\
\hline Simulation 1 & Fort Keraton Lipu \\
Simulation 2 & Office Complex Sara Ea \\
Simulation 3 & Fort and Sara Ea (no arrangement) \\
Simulation 4 & Fort and Sara Ea (with arrangement) \\
\hline
\end{tabular}

\section{f) End Stage}

Analyses and discussion on the result of determined simulation scenarios were conducted, by counting how many survivors that arrived at the evacuation site, and how many that did not survive.

\section{RESULT AND DISCUSSION}

North Buton Regency is a city located in the south end of Sulawesi Island, which geographically located on latitude of $4^{\circ} 06^{\prime}$ to $5^{\circ} 15^{\prime} \mathrm{S}$; and from West to East is $122^{\circ} 59^{\prime} \mathrm{E}$ up to $123^{\circ} 15^{\prime} \mathrm{E}$. There are several subdistricts in North Buton Regency that directly opposite the Banda Sea, yet in this research it would be limited to research area only of $2 \mathrm{~km} \times 1.5 \mathrm{~km}$. Therefore, there was only one sub-district that would be researched, which is Kulisusu Sub-district that covers Wandaka Village and Banu-banua Jaya Village. The data of total population and population density in the Kulisusu Subdistrict is of 22,688 people with density of 131.31 per $\mathrm{km}^{2}$ on 2015, which was acquired from Statistics Indonesia of North Buton Regency. Table 3 and Table 4 shows total population of Kalisusu sub-district based on age - sex, and its village.

Table 3. Population of Kulisusu sub-district (Lipu, Lakone, Wandaka, and Banu-banua Jaya) according to age and sex

\begin{tabular}{llll}
\hline Age Group & Male & Female & Total \\
\hline $0-4$ & 397 & 377 & 774 \\
$4-10$ & 393 & 371 & 764 \\
$10-20$ & 664 & 646 & 1310 \\
$20-30$ & 456 & 526 & 982 \\
$30-50$ & 794 & 803 & 1597 \\
$50-70$ & 334 & 343 & 677 \\
$>70$ & 47 & 72 & 119 \\
\hline Total & 3085 & 3138 & 6223 \\
\hline
\end{tabular}

The planned evacuation locations were Fort Keraton Lipu and Office Complex of Bumi Sara Ea; these locations have effective positions because it located on high elevation, and have good road access. The road condition to the evacuation location was an asphalt road, and only small amount was a hard dirt road; the road width was varied from 3 meters to 12 meters. The roads that relatively narrow were on Bajo Street and Geresa Street, while the wide ones were on Sara Ea Street, Murhum Street, Wa Ode Bilahi Street, and Minaminanga Street.

Table 4. Total population based on its village in the Kulisusu sub-district

\begin{tabular}{lllll}
\hline No & Village & $\begin{array}{l}\text { Area } \\
\left(\mathrm{km}^{2}\right)\end{array}$ & $\begin{array}{l}\text { Total } \\
\text { Population }\end{array}$ & $\begin{array}{l}\text { Density } \\
\text { per } \mathrm{km}^{2}\end{array}$ \\
\hline 1 & Lipu & 0.32 & 1839 & 57.47 \\
2 & Wandaka & 0.35 & 2921 & 83.46 \\
3 & Lakonea & 0.91 & 705 & 7.75 \\
4 & Banu- & 0.13 & 758 & 58.31 \\
& Banua Jaya & & & \\
\hline Total & & 1.71 & 6223 & 0.275 \\
\hline
\end{tabular}


Table 5. Aspects and indicators of preparedness behavior to tsunami disaster

\begin{tabular}{|c|c|}
\hline Parameter & Indicator of preparedness behavior against tsunami \\
\hline Knowledge of Tsunami and & 1. Know the tsunami signs \\
\hline \multirow[t]{5}{*}{ Intention } & 2. Know the causes of tsunami \\
\hline & 3. Know that the settlement is tsunami-prone \\
\hline & 4. Know the tsunami characteristics \\
\hline & 5. Know the characteristic of tsunami-resistant buildings \\
\hline & 6. Know the earthquake that causes tsunami \\
\hline Tsunami Disaster Response & 1. Know the importance of evacuation location \\
\hline \multirow[t]{5}{*}{ Plan } & 2. Know the importance of socialization about tsunami hazard \\
\hline & 3. Know about the awareness level of participating in socialization activity \\
\hline & 4. Planning on disaster response group \\
\hline & 5. Planning on preparedness to conducting evacuation \\
\hline & 6. Planning activities to raise awareness on possibility of tsunami \\
\hline \multirow[t]{9}{*}{ Tsunami Disaster Mitigation } & 1. Know about the tsunami early warning system \\
\hline & 2. Know the importance of early warning system \\
\hline & 3. Understand about tsunami-prone area map \\
\hline & 4. Planning evacuation when tsunami occurs \\
\hline & 5. Know about the available evacuation facilities \\
\hline & 6. Know the actions taken on evacuation \\
\hline & 7. Know the importance of mitigation effort \\
\hline & 8. Planning taken actions to increase government mitigation efforts \\
\hline & 9. Planning taken actions when tsunami occurs \\
\hline Resources Evacuation & 1. Know about evacuation drill \\
\hline \multirow[t]{7}{*}{ Mobilization } & 2. Know about preparedness in doing tsunami evacuations \\
\hline & 3. Know about the information on tsunami evacuation \\
\hline & 4. Planning evacuation facilities \\
\hline & 5. Training about evacuation \\
\hline & 6. Relocation Plan \\
\hline & $\begin{array}{l}\text { 7. Know about the importance of evacuation when tsunami occurs for the residents on } \\
\text { coastal area }\end{array}$ \\
\hline & 8. Plan for regional regulation on effort of preparedness to tsunami \\
\hline \multirow[t]{4}{*}{ Intention to do preparation } & 1. Find information about things to prepared when dealing with tsunami \\
\hline & 2. Find information about closest evacuation site location when tsunami occurs \\
\hline & 3. Checking the level of preparedness to tsunami \\
\hline & 4. Find information about intention to conduct evacuation simulation \\
\hline Preparedness to Tsunami & 1. Know the information about comprehension on preparedness \\
\hline \multirow[t]{3}{*}{ Disaster } & 2. The actions conducted in preparedness \\
\hline & 3. Setting up disaster standby groups \\
\hline & 4. Participation on preparedness activities \\
\hline
\end{tabular}

\subsection{Preparedness}

To discover the preparedness level of the community, this research referred to the preparedness components of LIPI UNESCO/ISDR (2006), which consisted of four parameters including knowledge on tsunami disaster, the tsunami disaster response plan, the tsunami disaster mitigation, and the resources evacuation mobilizations research. The aspects and indicators of preparedness to tsunami disaster could be seen in Table 5. A question would be considered valid if the r-calculate (Corrected Item - Total Correlation) $>$ from r-table value of product moment (two-tailed test). The value of r-table for 200 respondents was 0.138 . The test result for questionnaire as shown in Table 6 . The result of validity reliability test showed that for the point about intention and knowledge about tsunami, the KMO and Bartlett's Test score for correlation between variable was $>0.5$ (Table 7). The significance of research was 0.05 and $p<0.01$; which means the data was enough to be analyzed. The expected result for reliability test with Cronbach's alpha was $>0.30$. From the result, it is known that the acquired value for KMO test was above the required value, which was $0.63-0.91$, all of the acquired $p$ value was < 0.01; and the result for Cronbach's alpha value was 0.765 at lowest and 0.905 at highest. There were 3 items not valid, which were on the instrument of resources evacuation and the instrument of intention to conduct preparation; and also there was 1 item (no.9) on the tsunami mitigation variable which was not included because of the low discrimination power, under the loading factor value of 0.5 . 
Table 6. Result of validity test of the questionnaire

\begin{tabular}{|c|c|c|c|c|c|}
\hline Question & Validity Test & Note & Question & Validity Test & Note \\
\hline \multicolumn{3}{|l|}{ Knowledge of Tsunami } & \multicolumn{3}{|c|}{ Resources Evacuation Mobilization } \\
\hline Item No.1 (KOT1) & $0.563>0.138$ & Valid & Item No.33 (REM1) & $0.346>0.138$ & Valid \\
\hline Item No.2 (KOT2) & $0.583>0.138$ & Valid & Item No.34 (REM2) & $0.698>0.138$ & Valid \\
\hline Item No.3 (KOT3) & $0.507>0.138$ & Valid & Item No.35 (REM3) & $0.692>0.138$ & Valid \\
\hline Item No.4 (KOT4) & $0.424>0.138$ & Valid & Item No.36 (REM4) & $0.657>0.138$ & Valid \\
\hline Item No.5 (KOT5) & $0.378>0.138$ & Valid & Item No.37 (REM5) & $0.540>0.138$ & Valid \\
\hline Item No.6 (KOT6) & $0.431>0.138$ & Valid & Item No.38 (REM6) & $0.643>0.138$ & Valid \\
\hline Item No.7 (KOT7) & $0.508>0.138$ & Valid & Item No.39 (REM7) & $0.702>0.138$ & Valid \\
\hline \multicolumn{3}{|c|}{ Tsunami Disaster Response Plan } & Item No.40 (REM8) & $0.694>0.138$ & Valid \\
\hline Item No.8 (TRP1) & $0.487>0.138$ & Valid & Item No.41 (REM9) & $0.722>0.138$ & Valid \\
\hline Item No.9 (TRP2) & $0.551>0.138$ & Valid & Item No.42 (REM10) & $0.345>0.138$ & Valid \\
\hline Item No.10 (TRP3) & $0.369>0.138$ & Valid & Item No.43 (REM11) & $0.045<0.138$ & Not Valid \\
\hline Item No.11 (TRP4) & $0.462>0.138$ & Valid & Intention & & \\
\hline Item No.12 (TRP5) & $0.434>0.138$ & Valid & Item No.44 (INT 1) & $0.430>0.138$ & Valid \\
\hline Item No.13 (TRP6) & $0.498>0.138$ & Valid & Item No.45 (INT 2) & $0.413>0.138$ & Valid \\
\hline Item No.14 (TRP7) & $0.348>0.138$ & Valid & Item No.46 (INT 3) & $0.478>0.138$ & Valid \\
\hline Item No.15 (TRP8) & $0.553>0.138$ & Valid & Item No.47 (INT 4) & $0.498>0.138$ & Valid \\
\hline Item No.16 (TRP9) & $0.553>0.138$ & Valid & Item No.48 (INT 5) & $0.017<0.138$ & Not Valid \\
\hline Item No.17 (TRP10) & $0.512>0.138$ & Valid & Item No.49 (INT 6) & $0.111>0.138$ & Not Valid \\
\hline Tsunami Disaster Mitigation & & & Item No.50 (INT 7) & $0.319>0.138$ & Valid \\
\hline Item No.18 (TDM1) & $0.670>0.138$ & Valid & Item No.51 (INT 8) & $0.246>0.138$ & Valid \\
\hline Item No.19 (TDM2) & $0.375>0.138$ & Valid & Item No.52 (INT 9) & $0.317>0.138$ & Valid \\
\hline Item No.20 (TDM3) & $0.286>0.138$ & Valid & Item No.53 (INT 10) & $0.183>0.138$ & Valid \\
\hline Item No.21 (TDM4) & $0.626>0.138$ & Valid & \multicolumn{3}{|c|}{ Preparedness to Tsunami Disaster } \\
\hline Item No.22 (TDM5) & $0.625>0.138$ & Valid & Item No.54 (PTD1) & $0.407>0.138$ & Valid \\
\hline Item No.23 (TDM6) & $0.701>0.138$ & Valid & Item No.55 (PTD2) & $0.311>0.138$ & Valid \\
\hline Item No.24 (TDM7) & $0.683>0.138$ & Valid & Item No.56 (PTD3) & $0.458>0.138$ & Valid \\
\hline Item No.25 (TDM8) & $0.719>0.138$ & Valid & Item No.57 (PTD4) & $0.258>0.138$ & Valid \\
\hline Item No.26 (TDM9) & $0.342>0.138$ & Valid & & & \\
\hline Item No.27 (TDM10) & $0.690>0.138$ & Valid & & & \\
\hline Item No.28 (TDM11) & $0.675>0.138$ & Valid & & & \\
\hline Item No.29 (TDM12) & $0.644>0.138$ & Valid & & & \\
\hline Item No.30 (TDM13) & $0.726>0.138$ & Valid & & & \\
\hline Item No.31 (TDM14) & $0.720>0.138$ & Valid & & & \\
\hline Item No.32 (TDM15) & $0.433>0.138$ & Valid & & & \\
\hline
\end{tabular}

Table 7. Summary of data on item discrimination, validity, and reliability of questionnaire instrument

\begin{tabular}{lllllll}
\hline $\begin{array}{l}\text { Varia } \\
\text { ble }\end{array}$ & KMO & $\mathrm{p}$ & $\begin{array}{l}\text { Loading } \\
\text { Factor }\end{array}$ & $\begin{array}{l}\text { Cron- } \\
\text { bach's } \\
\text { Alpha }\end{array}$ & $\begin{array}{l}\Sigma \text { item } \\
\text { not } \\
\text { tested }\end{array}$ & $\begin{array}{l}\Sigma \text { item } \\
\text { after } \\
\text { test }\end{array}$ \\
\hline PTN & 0.80 & 0.00 & $0.52-0.75$ & 0.765 & 7 & 7 \\
TDB & 0.79 & 0.00 & $0.56-0.86$ & 0.802 & 10 & 10 \\
MBT & 0.91 & 0.00 & $0.53-0.85$ & 0.905 & 15 & 14 \\
ESD & 0.87 & 0.00 & $0.68-0.88$ & 0.881 & 11 & 10 \\
NT & 0.67 & 0.00 & $0.53-0.80$ & 0.624 & 10 & 8 \\
KBT & 0.63 & 0.00 & $0.52-0.77$ & 0.575 & 4 & 4 \\
\hline
\end{tabular}

On the calculation result of preparedness index value of each respondent, the distributed questionnaires were
200 samples on 4 villages in Kulisusu Sub-district. The value of total $\sum$ of each parameter index is:

Combined Parameter Index

$$
\begin{aligned}
& \frac{\sum K O T+\sum T R P+\sum T D M+\sum R E M+\sum I N T}{5} \\
& =\frac{71.15+56.63+47.18+48.82+61.68}{5}=57.09
\end{aligned}
$$

From the result of community preparedness index, the people of Kulisusu Sub-district was categorized as almost ready, with index value of 57.09 (Table 8). As follows is the average value from 5 parameters in the tsunami preparedness questionnaire. 
Table 8. Index of tsunami disaster preparedness in Kulisusu Sub-district, North Buton Regency

\begin{tabular}{lcl}
\hline Parameter & $\begin{array}{l}\text { Index } \\
\text { Value }\end{array}$ & Category \\
\hline $\begin{array}{l}\text { Knowledge on Tsunami } \\
\text { (KOT) }\end{array}$ & 71.15 & Ready \\
$\begin{array}{l}\text { Tsunami Disaster Response } \\
\text { Plan (TRP) }\end{array}$ & 56.63 & Almost Ready \\
$\begin{array}{l}\text { Tsunami Disaster Mitigation } \\
\text { (TDM) }\end{array}$ & 47.18 & Less Ready \\
$\begin{array}{l}\text { Resources Evacuation } \\
\begin{array}{l}\text { Mobilization (REM) } \\
\text { Intention (INT) }\end{array}\end{array}$ & 48.82 & Less Ready \\
Preparedness Index & 61.68 & Almost Ready \\
& 57.09 & Almost Ready \\
\hline
\end{tabular}

The result of index analysis shown that the highest value was on the parameter of knowledge on tsunami disaster, which is 71.15 and categorized as Ready; while the lowest value was on the tsunami disaster mitigation, which is 47.18 and categorized as less ready.

The Pearson product-moment correlation test was conducted to find whether there is a real connection between the parameter of intention to prepare before tsunami, with the community preparedness level to tsunami. The correlation test result used SPSS 20 program, which resulted in value $r=0.602$, with significance level $(\alpha)=0.05$; and $d f=n-2=200-2$ $=198$; therefore from the table $t$ of Pearson productmoment Correlation coefficient $($ table $t)$, the result $=$ $\mathrm{t}_{0.05,198}=1.972$.

$t=\frac{(r)(\sqrt{(n-2)}}{\sqrt{\left(1-r^{2}\right)}}=\frac{(0.602) \sqrt{(200-2)}}{\sqrt{1}}=10.61$

Value of $t$ calculate $(10.61)>t$ table (1.972), therefore H0 was rejected; which means there was a fairly strong correlation between the intention to prepare before tsunami, with the preparedness level to tsunami; with the correlation value, $r=0.602$.

\subsubsection{Confirmatory Factor Analysis}

Confirmatory analysis was conducted to explore the inter-relation pattern; therefore the matrix used was correlation matrix. The estimation process from SEM model in this research used the Maximum Likelihood Estimator (MLE); the program used was AMOS 20, which would convert questionnaire data to covariance or correlation form as the analysis input form (Ghozali, 2008).

To discover the influence of each variable, the regression weight value in the $\mathrm{CR}$ column was being noticed. The CR value was compared with its critical value, which was identic with $t$ calculate value which was \pm 1.65 on significance level of 0.05 , and the $t$ calculate value was \pm 2.34 on significance level of 0.01 . If the $C R$ value from processing result has exceeded its critical value with significance level $\mathrm{p}=0.05$ or $\mathrm{p}=0.01$; then it showed that the variable has significant influence to another variable (Table 9).

Value of regression weight on estimate column could also be used to see the influence of each variable; the estimated value compared with the standardized factor loadings are higher or equal with 0.50. Hair (1995) explained about relative importance and significant; if the factor loading of each item: factor loading $>0.50$; it means it's very significant, whereas the variable has a significant influence on another variable, and vice versa; if the value is under 0.50 ; the variable does not influence another variable. The result from this output was shown in Figure 2.

Based on the result of SEM model analysis, the model for tsunami preparedness was over-identified. With the total sample $n=200$, the total of covariance data was 1431, while the total estimated parameters were 123 . From this result, the degree of freedom obtained is $1431-123=1308 ; 1308>0$, therefore the model was over-identified, which means the estimation of the model could be identified.

Table 9. Evaluation Result of SEM Model Parameter

\begin{tabular}{|c|c|c|c|c|c|}
\hline Path & $\begin{array}{l}\beta \\
\text { Estima } \\
\text { te }\end{array}$ & SE & $\mathrm{CR}$ & $\begin{array}{l}\text { sig } \\
\text { nif } \\
\text { ica } \\
\text { nc } \\
\text { e }\end{array}$ & Conclusion \\
\hline $\begin{array}{l}\text { KBT } \leftarrow \\
\text { TDB }\end{array}$ & 0.519 & 0.271 & 1.912 & $*$ & Significant \\
\hline $\begin{array}{l}\mathrm{KBT} \leftarrow \\
\mathrm{MBT}\end{array}$ & -0.055 & 0.303 & -0.181 & - & ns \\
\hline $\mathrm{KBT} \leftarrow \mathrm{ESD}$ & -0.021 & 0.230 & -0.090 & - & ns \\
\hline $\mathrm{KBT} \leftarrow \mathrm{PTN}$ & 0.157 & 0.093 & 1.681 & $*$ & Significant \\
\hline $\mathrm{KBT} \leftarrow \mathrm{NT}$ & 0.540 & 0.142 & 3.818 & $* *$ & Significant \\
\hline
\end{tabular}

To be able to assess the criteria from abovementioned SEM model is by looking how far the model that was hypothesized to be 'fit' or match with the data sample. The result of goodness of fit shown that the value of chi-square was 3939.05 with $d f=1317$, and the probability value was 0.00 . This result showed that the model was categorized in marginal, therefore the model could be used for observation. Result wass shown in Table 10. 


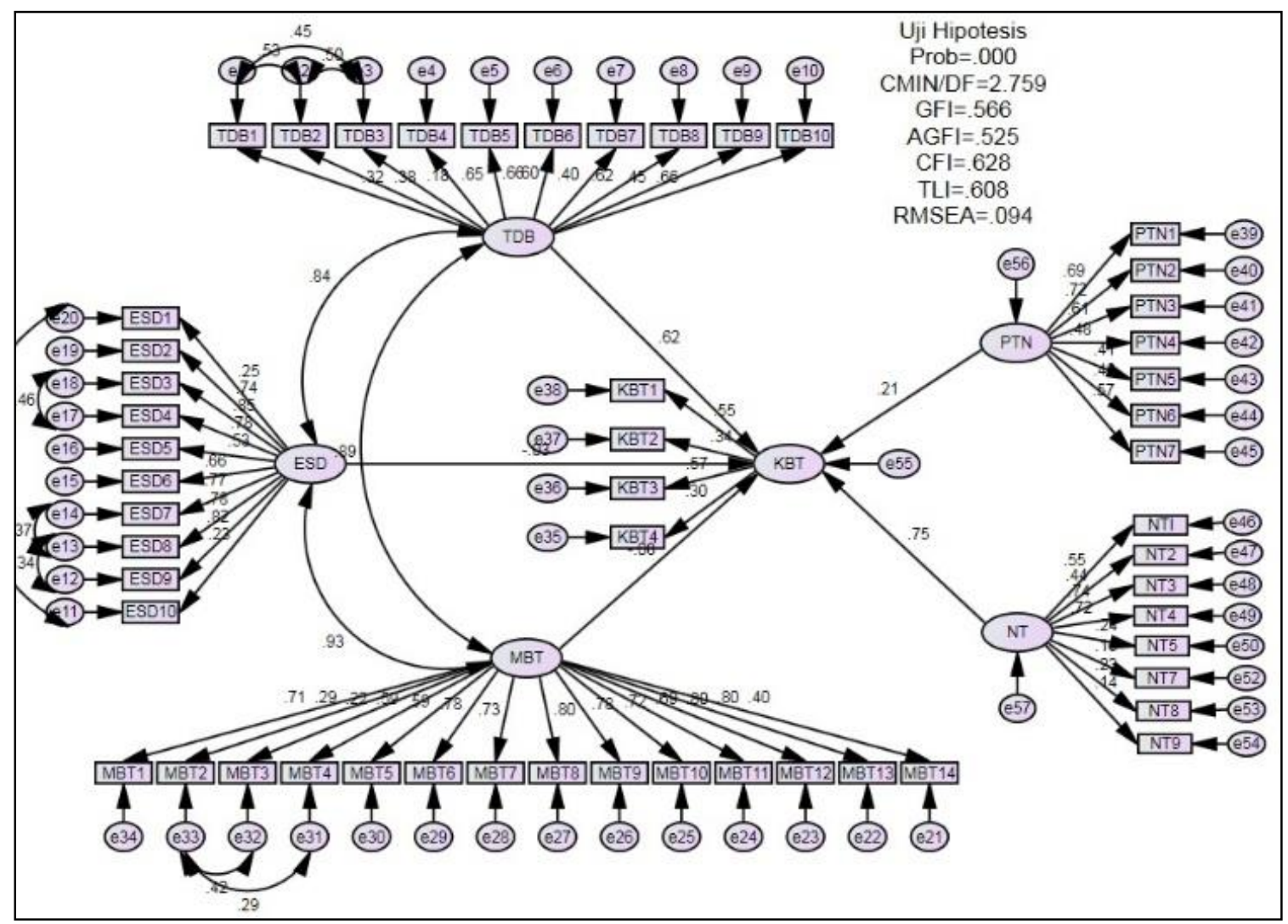

Figure 2. Model on structural equation of tsunami preparedness

Regression coefficient between element of intention to preparedness effort showed a significant result; which means that the intention indicators are very influential to the preparedness effort that is presently conducted. This element has huge contribution to the tsunami disaster preparedness in Kulisusu Sub-district.

Table 10. Summary of goodness of fit model criteria

\begin{tabular}{llll}
\hline $\begin{array}{l}\text { Goodness of Fit } \\
\text { Indeks }\end{array}$ & $\begin{array}{l}\text { Cut off } \\
\text { Value }\end{array}$ & Result & Evaluation \\
\hline CMIN/DF & $<5.00$ & 2.76 & Good \\
GFI & $>0.90$ & 0.57 & Marginal \\
CFI & $>0.90$ & 0.63 & Marginal \\
AGFI & $>0.90$ & 0.53 & Marginal \\
RMSEA & $\leq 0.08$ & 0.09 & Marginal \\
\hline
\end{tabular}

\subsubsection{Tsunami Evacuation Simulation}

The data acquired was processed with Evacuware Version 2.0 Software in 2011. The determination of evacuation location plan was based on field observation.

\section{a) Fort Keraton Lipu Complex}

This is one of the housing complexes; which is located in the Wasalabose Village, Kulisusu Sub-district.

b) Office Complex Bumi Sara Ea
Office Complex Bumi Sara Ea is a complex of North Buton Regency government service that is located in Sara Ea Village, Kulisusu Sub-district.

c) Fort Keraton Lipu Complex and Office Complex Bumi Sara Ea

Of these two evacuation location, evacuation simulation would be held by using the assumption that residents are to freely choose the location (Figure 3).

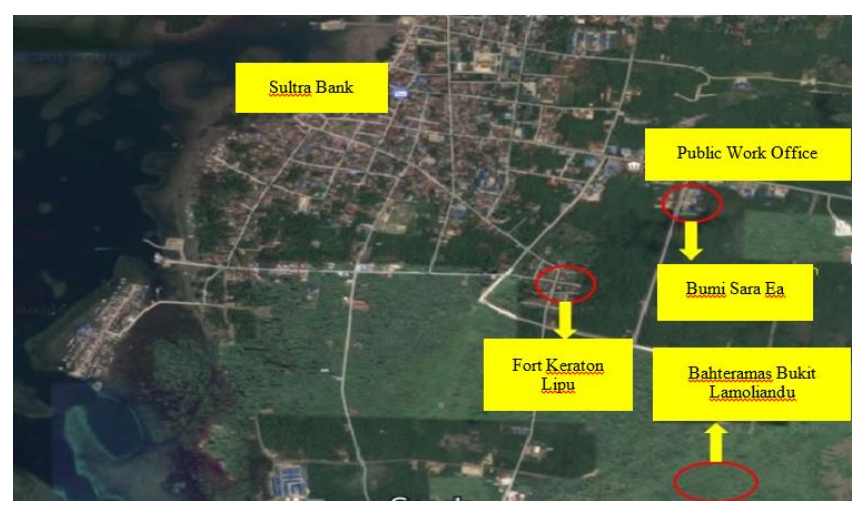

Figure 3. Evacuation location on google maps

d) Condition of Evacuation Path

Condition of evacuation path can be seen in Figure 4 and Figure 5. The material condition of evacuation path was asphalt road. According to the filed observation, 
the widths of the evacuation paths were varied from 3 meters to 12 meters. The widest paths were on Sara Ea Street and Stadion Street, while the narrowest was on the Banu-banua Jaya Village Street.

Because the topography of North Buton Regency coastal area is lowland, most of the existing evacuation paths were flat roads. The uphill part was the path to Bahteramas Stadium and Office Complex Bumi Sara Ea. The above differences were very influential during the evacuation process. To address the problem, the friction value was used to represent the above conditions.
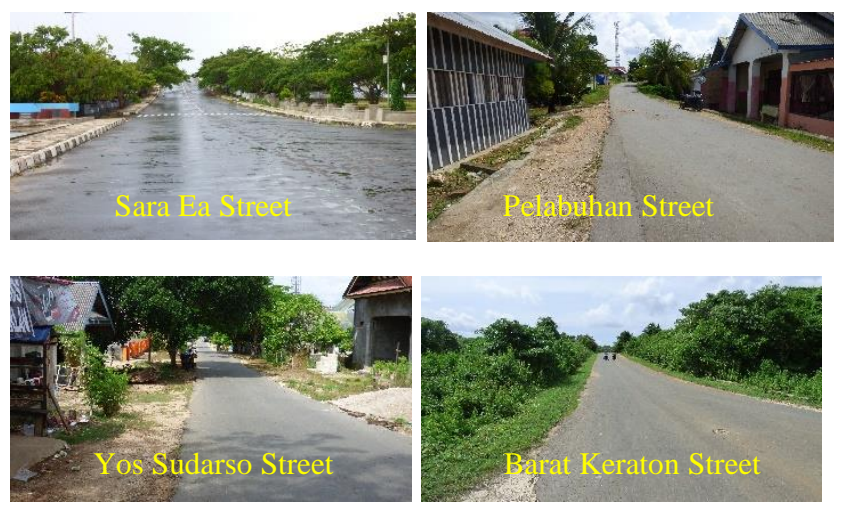

Figure 4. Condition of Evacuation Path of Office Complex Bumi Sara Ea
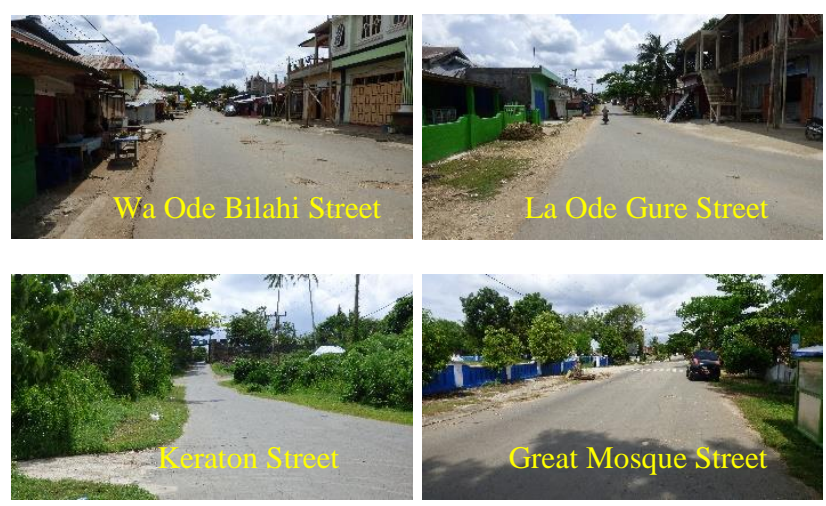

Figure 5. Condition of Evacuation Path to the Fort Keraton Lipu Complex

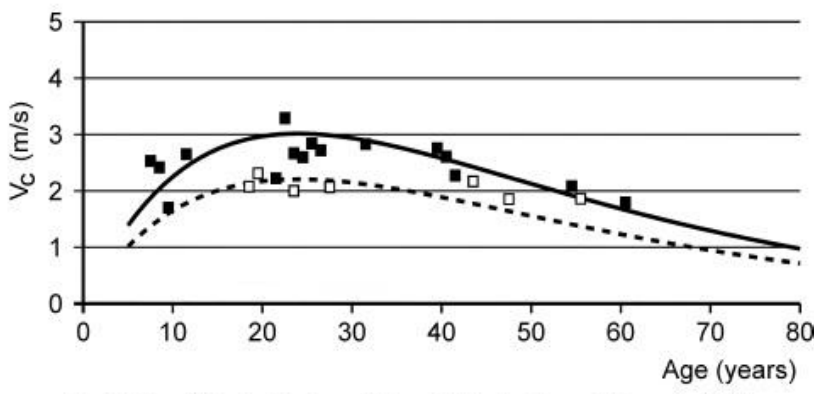

- Eq. 1, $C=8.2, k=1, A o=24$ Male Normal People $800 \mathrm{~m}$ -.. Eq. 1, $C=6, k=1, A_{0}=24 \quad$ Female Normal People $800 \mathrm{~m}$

Figure 6. Average running speed of Indonesian at $800 \mathrm{~m}$ of distance (Triatmadja, 2015)
On the Evacuware Software, there were several determined parameters in evacuation, which are human strength and speed, which was randomly given based on the parameter value. Determining the average running speed of the appropriate person had been conducted in the evacuation simulation on Parangtritis (Triatmadja, 2015); the average running speed of a more appropriate person could be seen in Figure 6 . From the Figure 6, it could be seen that the running speed when in asphalt road was used as to represent the average running speed ability of people during the evacuation.

Table 11. Friction Value (Triatmadja, 2015)

\begin{tabular}{lll}
\hline No & Evacuation Road & $\begin{array}{l}\text { Friction Value } \\
(\%)\end{array}$ \\
\hline 1 & Asphalt Road & 1 \\
& a. Flat & 0.9 \\
& b. Slope $1: 10$ & 0.8 \\
& c. Slope $1: 5$ & $0.4-0.5$ \\
& d. Slope $1: 2$ & 0.4 \\
2 & Stairs & $0.4-0.8$ \\
3 & a. Slope $1: 6$ & $0.6-0.8$ \\
4 & Slippery Road & 0.9 \\
5 & Flat Macadam Road &
\end{tabular}

Table 11 shows that the friction value of running human on asphalt road is 1 , on hard soil ground is 0.95 ; and on sand soil surface is 0.85 . Whereas in Table 12 is the parameter used in the simulation evacuation.

Table 12. Human parameter value for evacuation simulation

\begin{tabular}{|c|c|c|c|}
\hline \multicolumn{4}{|l|}{ Running Capacity } \\
\hline Male Evacuee & & Female Evacuee & \\
\hline Age of Maximum & & Age of Maximum & \\
\hline Capacity & 24 & Capacity & : 24 \\
\hline Power & 1 & Power & 1 \\
\hline $\mathrm{C}$ for $\operatorname{Man}(\mathrm{m} / \mathrm{s})$ & : 8.2 & $\mathrm{C}$ for $\operatorname{Man}(\mathrm{m} / \mathrm{s})$ & $: \quad 6.0$ \\
\hline
\end{tabular}

From the Scenario 1 simulation result, the location of Fort Keraton Lipu is actually could already be used as a safe location from tsunami disaster, which could be seen from its fairly wide space capacity; however from the simulation result, it is shown an accumulation on the access path to the evacuation location, in which the road access to the location is a hilly road and a relatively narrow road into the Fort Keraton Lipu. This is seen in simulation 1 result, which in the time period of $\leq 20$ minutes, the number of residents that could reach the location of Fort Keraton Lipu was 58.60\%; while on minutes to sixty, there was only $79.13 \%$ that survived. Figure 7 shows the shelter location on Simulation 3. 


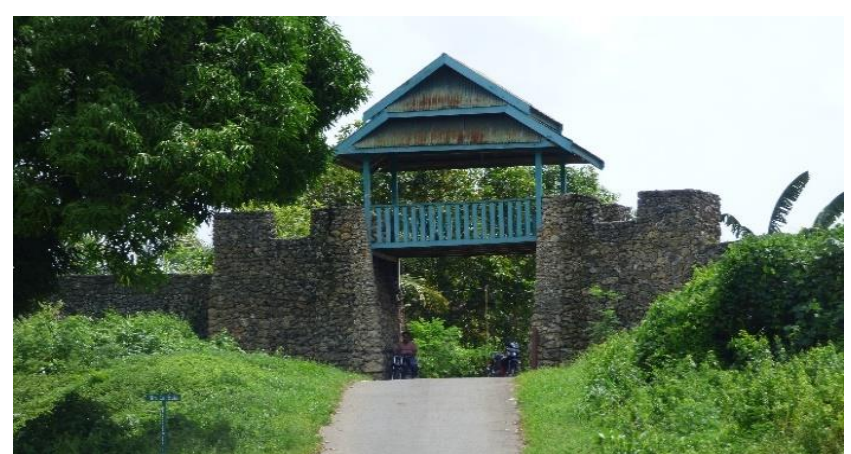

Figure 7. Evacuation location simulation 3 in Fort Keraton Lipu and Office Complex Sara Ea

Factors that affected the number of survivors is the condition of evacuation path, the density level, the community condition, the path width, good road condition, and the slope of the evacuation road also affected the space during evacuation. The evacuation path to the Fort Keraton Lipu Complex was practically good, but the path was relatively narrow and hilly (Figure 8). Details of evacuation simulation process can be seen in Figure 9. Points color indicate the range of the age.

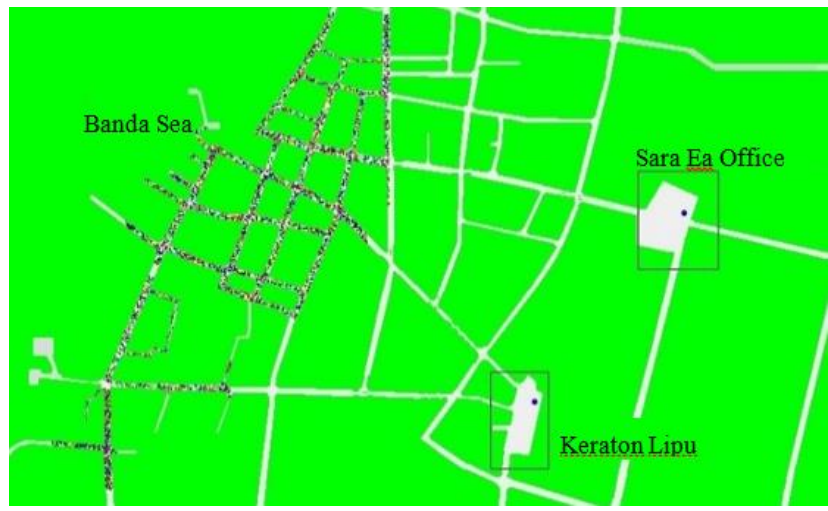

Figure 8. Path of Entrance Access to Fort Keraton Lipu

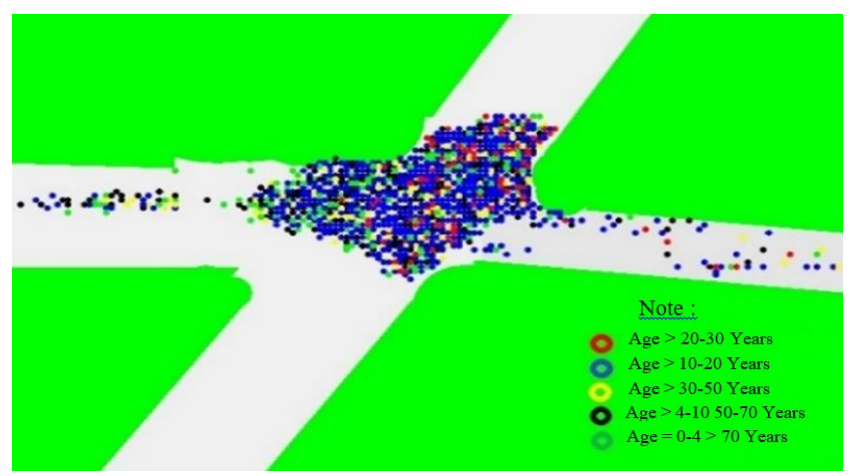

Figure 9. Details of evacuation simulation process

A different result could be seen in Simulation 3, in which the total of survived resident increased $9.6 \%$ on $60^{\text {th }}$ minute compared to Simulation 1 result; and increased $0.25 \%$ on $60^{\text {th }}$ minute compared to Simulation 2 result. This was because the residents chose the closest location which was relatively easy to be reached, even though the location would be obstructed because of the number of residents that go into one direction at the same time, which could cause congestion. The result could be seen in Table 13.

Table 13. Total number of survived residents'

\begin{tabular}{llllll}
\hline \multirow{2}{*}{$\begin{array}{l}\text { Time } \\
\text { (minute) }\end{array}$} & $\begin{array}{l}\text { Total } \\
\text { Resident }\end{array}$ & \multicolumn{4}{l}{$\begin{array}{l}\text { Simulation of Survived Resident } \\
\text { (person) }\end{array}$} \\
\cline { 3 - 6 } 1 & 1 & 2 & 3 & 4 \\
\hline 5 & 6223 & 147 & 142 & 289 & 298 \\
10 & 6223 & 1190 & 1408 & 2001 & 2143 \\
15 & 6223 & 2116 & 2862 & 2526 & 3087 \\
20 & 6223 & 2774 & 4155 & 2981 & 3405 \\
25 & 6223 & 3618 & 5014 & 3389 & 4613 \\
30 & 6223 & 4281 & 5685 & 4086 & 5045 \\
35 & 6223 & 4832 & 6121 & 4548 & 5503 \\
40 & 6223 & 5450 & 6222 & 4941 & 6223 \\
45 & 6223 & 5780 & 6223 & 5315 & - \\
50 & 6223 & 5835 & - & 5788 & - \\
55 & 6223 & 5892 & - & 5966 & - \\
60 & 6223 & 5913 & - & 6100 & - \\
\hline
\end{tabular}

Confusion, age, and sex also affect the results. Accumulation on one evacuation point occurs which could cause higher disaster risk, while the other evacuation locations are empty. Comparison percentage on result of simulation 1,2,3 and 4 can be seen in Table 14.

Table 14. Comparison percentage on result of simulations

\begin{tabular}{llllll}
\hline \multirow{2}{*}{$\begin{array}{l}\text { Time } \\
\text { (minute) }\end{array}$} & Total & \multicolumn{4}{c}{ Simulation of Survived Resident (\%) } \\
\cline { 3 - 6 } & Resident & 1 & 2 & 3 & 4 \\
\hline 5 & 6223 & 2.36 & 2.28 & 4.46 & 4.79 \\
10 & 6223 & 19.12 & 22.62 & 32.15 & 34.44 \\
15 & 6223 & 34.00 & 45.99 & 40.59 & 49.60 \\
20 & 6223 & 44.57 & 66.76 & 47.90 & 54.71 \\
25 & 6223 & 58.14 & 80.57 & 54.45 & 74.13 \\
30 & 6223 & 68.79 & 91.35 & 69.43 & 81.07 \\
35 & 6223 & 77.65 & 98.36 & 76.29 & 88.43 \\
40 & 6223 & 87.57 & 99.98 & 82.50 & 100 \\
45 & 6223 & 92.88 & 100 & 90.92 & - \\
50 & 6223 & 93.76 & - & 95.09 & - \\
55 & 6223 & 94.68 & - & 96.61 & - \\
60 & 6223 & 95.02 & - & 98.02 & - \\
\hline
\end{tabular}

Figure 10 and Figure 11 indicate that by simultaneously using 2 shelters, Simulation 4 increased $1.98 \%$ from Simulation 3; this was influenced by the presence of alternative access path and the shorter travel time to evacuation location. It could be observed on the graph 
that the increase of total survived residents that arrived safely to the final evacuation site was started from $10^{\text {th }}$ minute up to $30^{\text {th }}$ minute; in Simulation 3, the total of survived residents was of $98.02 \%$, this was due to the congestion in the access path through the Fort Keraton Lipu, in which the evacuation time became longer, even the residents that were running to the closest location resulted in congestion, although there were other access points that could be passed.

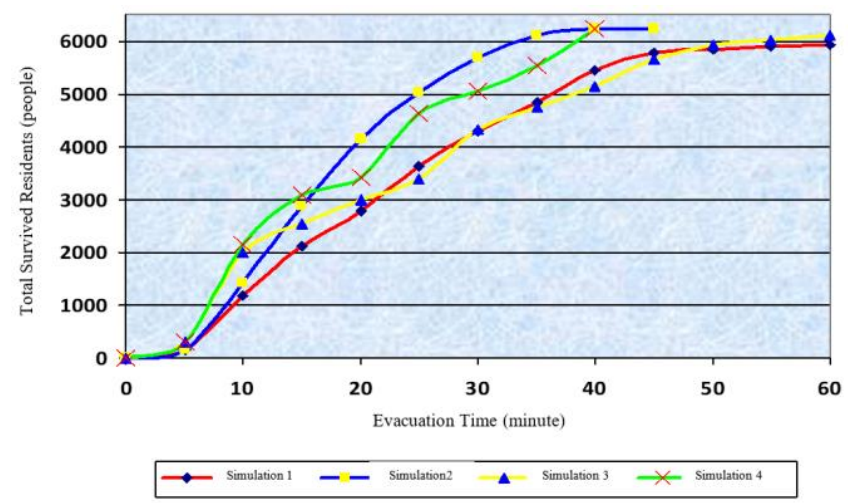

Figure 10. Total survived residents to time at simulation 1, 2,3 and 4

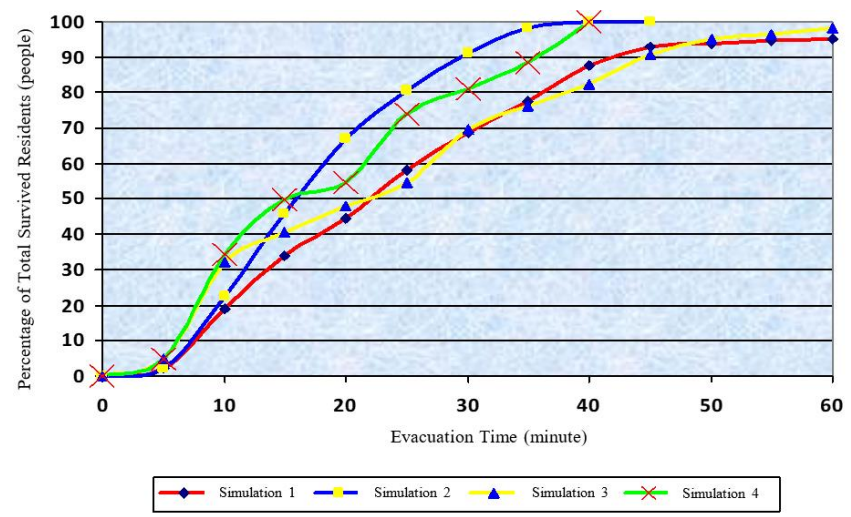

Figure 11. Percentage of total survived residents to time at simulation $1,2,3$ and 4

\section{CONCLUSION}

Based on the result of conducted research, several matters could be concluded as follows:

a) The preparedness level on facing the tsunami disaster threat of the community in North Buton Regency, Kulisusu Sub-district, particularly those located in the coastal area-which are Lipu Village, Lakonea Village, Wandaka Village, and Banubanua Jaya Village-were categorized in Almost Ready; with the preparedness index value of 57.09.

b) The element of intention in the community preparedness effort in North Buton Regency was an important factor; in which the element of intention is an individual factor on the community that could influence the surrounding environment, in order to increase the preparedness effort. c) The result of tsunami disaster evacuation simulation that simultaneously used shelter locations of Fort Keraton Lipu and Office Complex Bumi Sara Ea showed that the needed time for evacuation was 40 minutes; therefore it is worthy to be an evacuation site with percentage of survived residents of $100 \%$.

d) The opportunity for community evacuation would be greater if it is supported by good facilities and infrastructures, and the level of understanding on the community about the preparedness and the danger of tsunami disaster that could happen at any time.

\section{SUGGESTIONS}

By noting the result of the conducted research, writer could give some suggestions as follows:

a) Evacuation signs such as directions, information board on the path and location evacuation need to be built by the government of North Buton Regency, as an early mitigation effort; because the coastal area in the Kulisusu Sub-district is the area with the highest population in North Buton Regency.

b) The necessity for regional regulation on coastal area; in this case, the National Spatial Plan on disaster-prone coastal area

\section{REFERENCES}

Badan Pusat Statistik Kabupaten Buton Utara, 2015. Kabupaten Buton Utara dalam Angka. [Online].

Dharmady, D., 2014. Simulasi Kesiapsiagaan Tsunami di Kota Bandar Lampung, Yogyakarta: Master of Engineering in Natural Disaster Management UGM.

Ghozali, I., 2008. Model Persamaan Struktural Konsep dan Aplikasi dengan Program AMOS 16, Semarang: Diponegoro University.

Hair, J. F., Tatham, L. \& Rolph, A. E., 1995. Multivariate Data Analysis with Readings. New Jersey: Prentice Hall.

Munadi, K. et al., 2012. Pengembangan Simulasi Evakuasi Bencana Tsunami Berbasis Multiagent System. Banda Aceh.

Nasution, S., 2014. Simulasi Evakuasi Tsunami Di Kota Bengkulu (Studi kasus: Kelurahan Malabero dan Kelurahan Sumur Meleleh), Yogyakarta: Universitas Gadjah Mada.

Nugroho, A. C., 2006. Kajian Kesiapsiagaan Masyarakat dalam Mengantisipasi Bencana Gempa Bumi dan Tsunami. Jakarta: MPBI-UNESCO. 
Nurhayaty, A., 2015. Model Kesiapsiagaan Terhadap Bencana Tsunami pada Masyarakat di daerah rawan Tsunami, Yogyakarta: Dissertation Report, Universitas Gadah Mada.

Rhamo, A., 2014. Studi Penentuan Lokasi Evakuasi Vertikal di Pantai Parangtritis, Yogyakarta: Universitas Gadjah Mada.

Saifuddin, A., 1998. Sikap Manusia: Teori dan Pengukurannya. Yogyakarta: Pustaka Penerbit.
Triadmodjo, B., 1999. Teknik Pantai. Yogyakarta: Beta Offset.

Triatmadja, R., 2015. Numerical Simulation of An Evacuation From Tsunami at Parangtritis Beach in Indonesia. Journal of Tsunami Sciety International Volume 34 No 1. 